\title{
Holocene vegetation and climate history of the northern Golan heights (Near East)
}

Frank Neumann • Christian Schölzel • Thomas Litt • Andreas Hense • Mordechai Stein

Published online: 9 February 2007

(C) Springer-Verlag 2006

\section{Veget Hist Archaeobot (2006) \\ Dol 10.1007/s00334-006-0046-x}

Unfortunately the following quotations are missing in the published article:

Caption of Table 1: Changed after Schwab et al. 2004

Caption of Fig. 3: After Schwab et al. 2004

The online version of the original article can be found at http://dx.doi.org/10.1007/s00334-006-0046-x

F. Neumann · T. Litt $(\square)$

Institute for Palaeontology, University of Bonn,

Nussallee 8,

53115 Bonn, Germany

e-mail: t.litt@uni-bonn.de

C. Schölzel · A. Hense

Meteorological Institute, University of Bonn,

Auf dem Hügel 20,

53121 Bonn, Germany

M. Stein

Geological Survey of Israel,

30 Malkhei Israel Street, Jerusalem 95501, Israel 